\title{
Zinc Finger Protein ZFPM1
}

National Cancer Institute

\section{Source}

National Cancer Institute. Zinc Finger Protein ZFPM1. NCI Thesaurus. Code C84288.

Zinc Finger Protein ZFPM1 (1004 aa, 105 kDa) is encoded by the human ZFPM1 gene.

This protein is involved in the regulation of transcription. 